\title{
Активность и каталитические свойства глутатионпероксидазы при токсическом поражении печени
}

\author{
® 2019 Шульгин К.К. ${ }^{1}$, Попов С.С. ${ }^{2}$, Веревкин А.Н. ${ }^{1}$, \\ Попова Т.Н. ${ }^{1}$, Семенихина А.В. ${ }^{1}$ \\ ${ }^{1}$ Воронежский государственный университет, Воронеж \\ ${ }^{2}$ Воронежский государственный медицинский университет им. Н.Н. Бурденко \\ Министерства здравоохранения Российской Федерации, Воронеж
}

Поступила в редакцию 28.11.2019 г.

DOI: $10.17308 /$ sorpchrom.2020.20/2385

Целью работы было изучение активности глутатионпероксидазы (ГП, КФ 1.11.1.9.) при нарушении функции печени, а также очистка фермента с применением хроматографических методов для дальнейшего изучения кинетических свойств. В эксперименте использовали сыворотку крови пациентов с алкогольным гепатитом, находящихся на лечении в стационаре. В качестве группы сравнения в исследование были включены практически здоровые лица с нормальными показателями общего и биохимического анализов крови. Экспериментальный токсический гепатит (ЭТГ) моделировали путем перорального введения четыреххлористого углерода самцам белых лабораторных крыс (Rattus norvegicus) Wistar. В контрольную группу входили животные, находящиеся на стандартном режиме вивария. Активность ГП определяли спектрофотометрически при длине волны 340 нм. с помощью сопряженной ферментативной реакции с глутатионредуктазой. Очистку ГП из печени крысы в нормальных условиях и при ЭТГ проводили путем гомогенизации материала, гель-фильтрации на Сефадекс G-25, ионообменной хроматографии на ДЭАЭ-целлюлозе, концентрирования фракций фермента с помощью ультрафильтрации на ячейке Amicon, гель-хроматографии на Toyopearl HW-65. Чистоту полученного ферментного препарата оценивали электрофоретическим методом. Общее количество белка в пробах определяли по методу Лоури. Показано возрастание активности маркерных ферментов развития патологии в сыворотке крови пациентов с заболеванием печени и крыс с ЭТГ. Также обнаружено изменение активности ГП в сыворотке крови больных алкогольным гепатитом и в гомогенате печени крыс при ЭТГ по сравнению с контрольным уровнем. В ходе эксперимента были получены ферментные препараты из печени контрольных животных и крыс с ЭТГ с удельной активностью 1.46 и 3.64 Е/мг; с выходом 7.2 и 8.0\% соответственно. В дальнейшем они использовались для изучения кинетических свойств ГП. Установлено, что при токсическом гепатите ГП менее устойчива к длительному воздействию температур по сравнению с ферментом из печени контрольных животных. Кроме того, при патологии происходит возрастание температурного оптимума и константы инактивации. На основании полученных результатов можно предположить, что изменение активности фермента при нарушении функции печени может быть связано с конформационными перестройками его молекулы в условиях повышенной генерации свободных радикалов.

Ключевые слова: токсический гепатит, глутатионпероксидаза, активность, очистка.

\section{Введение}

В настоящее время в условиях все возрастающего поступления в организм человека ксенобиотиков актуальной проблемой современной медицины остаются заболевания печени, которыми страдает 15-30\% людей, но это та часть, которая обращается за медицинской помощью. Этиология токсического гепатита может быть 
связана с хроническим и чрезмерным употреблением алкоголя, приемом лекарственных препаратов, нарушениями липидного и углеводного обмена и другими факторами. Многие вопросы патогенеза, диагностики и лечения токсического гепатита в настоящее время требуют дальнейших исследований, что в особенности относится к их молекулярным основам.

Известно, что баланс между скоростью генерации и инактивации свободных радикалов лежит в основе нормального функционирования печени и нарушение такого равновесия приводит к развитию патологии. Так, при алкогольном гепатите (АГ), являющимся значимой медико-социальной проблемой, около $90 \%$ принимаемого алкоголя метаболизируется в печени с образованием ацетальдегида, который обладает гепатотоксическим действием, проявляющимся в результате усиления процессов пероксидного окисления липидов (ПОЛ), нарушения структурнофункционального состояния белков, нуклеиновых кислот, повреждения клеточных мембран [1]. Интенсивность свободнорадикальных процессов в организме контролируется антиоксидантной системой, важным компонентом которой является глутатионпероксидазная/ глутатионредуктазная (ГП/ГР) ферментативная антиоксидантная система (АОC), защищающая клетки от органических и неорганических пероксидов, с использованием в качестве донора водорода восстановленного глутатиона (GSH) [2]

В связи с вышесказанным целью данной работы явилась оценка активности ГП у здоровых доноров и больных АГ, в печени крыс в норме и при токсическом гепатите, а также исследование каталитических свойств данного фермента, очищенные препараты которого были получены с использованием хроматографических методов.

\section{Эксперимент}

В клиническое исследование было включено 74 человека с АГ, развивающимся вследствие хронического употребления алкоголя, все больные были мужско-

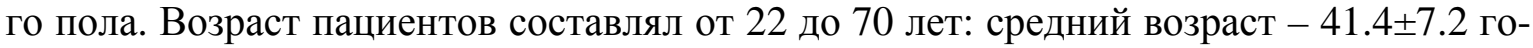
да. Средняя продолжительность заболевания составляла $6.2 \pm 0.4$ месяца. В ходе клинического исследования использовали кровь больных, находящихся на лечении в стационаре (ГУЗ ВОКПД им. Н.С. Похвисневой, КУЗВО «Воронежский областной клинический психоневрологический диспансер»). Контрольную группу составили 65 практически здоровых лиц в возрасте от 21 до 52 лет с нормальными показателями общего и биохимического анализов крови. Критериями исключения из исследования явились: вирусные гепатиты, злокачественные новообразования, сахарный диабет, острый инфаркт миокарда, острое нарушение мозгового кровообращения, хроническая почечная недостаточность. Кровь для исследования забиралась в пробирки типа «вакутейнер» в утреннее время, натощак, из локтевой вены. При проведении исследований соблюдались необходимые этические нормы. Проводимые исследования были одобрены Этическим комитетом Воронежского государственного медицинского университета им. Н.Н. Бурденко.

В качестве объекта исследования использовали также самцов белых лабораторных крыс (Rattus norvegicus) Wistar массой 150-200 г. (питомник лабораторных животных КролИнфо, Россия, Московская обл.). Все манипуляции были выполнены в соответствии с правилами гуманного обращения с лабораторными животными (Директива2010/63/EU Европейского Парламента и Совета Европейского Союза от $22.09 .2010)$ и санитарными нормами вивариев (ГОСТ 33216-2014). Для моделирования экспериментального токсического гепатита (ЭТГ) использовали четыреххлористый углерод, являющийся органоспецифичным токсином, обладающим гепато- 
тропным действием. $\mathrm{CCl}_{4}$ вводили животным однократно перорально после суточной пищевой депривации в дозе $0.064 \mathrm{~cm}^{3}$ на 100 г веса животного в виде раствора в вазелиновом масле [3]. Печень забирали на 4-е сутки, когда наблюдался максимальный цитолиз гепатоцитов.

Печень перед извлечением из брюшной полости перфузировали in situ ледяным $0.9 \%$ раствором $\mathrm{NaCl}$ через $v$. portae. Затем ее гомогенизировали с использованием гомогенизатора Daihan HG-15A в 4x-кратном объеме охлажденной среды выделения (50 мМ трис-НС1-буфер (pН 7.8), содержащий 1 мМ ЭДТА, 1\% 2-меркаптоэтанол),

Вытяжку тканей, полученную в результате гомогенизации, фильтровали через слой капрона, размер ячеек которого составлял 0.1 мм. Не разрушенные клетки, обломки клеток и ядра отделяли центрифугированием при 5 тыс. об/мин в течение 10 мин. После этого, осадок отбрасывали, а супернатант использовали для дальнейших исследований.

Активность ГП определяли спектрофотометрически при длине волны 340 нм. Измерение активности ГП проводили с помощью сопряженной ферментативной реакции в среде спектрофотометрирования следующего состава: 50мМ калийфосфатный буфер (рН 7.4), содержащий 1 мМ ЭДТА, 0.12 мМ НАДФН, 0.85 мМ восстановленного глутатиона, 0.37 мМ $\mathrm{H}_{2} \mathrm{O}_{2}, 1$ ед/см${ }^{3}$ ГР. Контрольная проба не содержала восстановленный глутатион. Реакцию начинали добавлением ферментного препарата. За единицу ферментативной активности (Е) принимали количество фермента, катализирующее образование 1 мкмоль продукта реакции или превращение 1 мкмоль субстрата за 1 мин при температуре $+25^{\circ} \mathrm{C}$.

Очистку ГП из печени крыс осуществляли с помощью гель-фильтрации через сефадекс G-25 и Toyopearl HW-65, а также ионообменной хроматографии через ДЭАЭ-целлюлозу.

При проведении гель-фильтрации через сефадекс G-25 (Fine, 1.7×20 см) ферментный препарат наносили на колонку в количестве не более $20-25 \%$ от ее объема. В качестве элюирующей среды для ГП использовали 0.05 М трис-HCl-буфер, pH 7.6, содержащий 1 мМ ЭДТА. Скорость элюции составляла 25-30 см $3 /$ ч. Каждую фракцию объёмом 2-3 см ${ }^{3}$ анализировали на присутствие ферментативной активности. Фракции, обладающие максимальной ферментативной активностью, объединяли и использовали для дальнейшей очистки.

Для фракционирования белков использовали также ионообменную хроматографию на колонке с ДЭАЭ-целлюлозой $(0.8 \times 13$ см). На данной стадии очистки использовали среду элюции того же состава, что и на предыдущей. Скорость элюции составляла 20-25 см 3 ччас. Каждую фракцию объемом 1.5 мл анализировали на присутствие ферментативной активности и на содержание белка.

Фракции с максимальной активностью фермента объединяли и концентрировали с помощью ячейки Amicon под давлением азота 4.2 атм. и скоростью истечения 20 мл/час. Использовали мембраны, пропускающие буферный ферментный раствор с низкомолекулярными белками (до 50 кДа). Полученный ферментный препарат подвергали дальнейшей очистке на колонке с Tоуоpearl HW-65. Калибровку осуществляли с помощью набора белков-метчиков с известными молекулярными массами. Элюцию проводили со скоростью $20 \mathrm{~cm}^{3} /$ час средой того же состава, что и на предыдущих стадиях с добавлением $100 \mathrm{MM} \mathrm{KCl.} \mathrm{Фракции,} \mathrm{объемом} 1.5 \mathrm{~cm}^{3}$, анализировали на присутствие ферментативной активности и содержание белка. Оценку чистоты полученных после заключительной стадии очистки ферментных препаратов проводили методом электрофореза в ПААГ [4], используя для проявления на белок нитрат серебра [5]. 
Общее количество белка в пробах определяли по методу Лоури [6]. Все процедуры выделения и очистки фермента проводили при температуре $0-4^{\circ} \mathrm{C}$.

Опыты проводили в 4-кратных биологических и 2-кратных аналитических повторностях. Для обработки результатов исследования использовали описательную статистику с определением выборочного среднего, выборочного стандартного отклонения, стандартной ошибки среднего [7]. Результаты работы анализировали, используя t-критерий Стьюдента для множественных сравнений с поправкой Бонферрони. Нормальность распределения значений оценивалось с помощью критерия Колмогорова-Смирнова. Достоверными считали различия при р <0.05.

\section{Обсуждение результатов}

Показателями развития патологии печени является изменение активности маркерных ферментов (аспартатаминотрансферазы (АСАТ), аланинаминотрансферазы (АЛАТ)). Так, у пациентов с АГ активность АСАТ возрастала в 2.9 раза, АЛАТ 2.5 раза. В ходе проведенных исследований установлено, что активность ГП, выраженная в Е на мл сыворотки, у больных АГ снижалась в среднем в $1.6(\mathrm{p}<0.05)$ раза по сравнению с контрольным уровнем. Удельная активность фермента уменьшалась в $1.9(\mathrm{p}<0.05)$ раза по сравнению с нормой. По-видимому, снижение активности ГР при алкогольном гепатите может вносить существенный вклад в уменьшение содержания восстановленного глутатиона в данных условиях. Наблюдаемое падение активности ГП, очевидно, взаимосвязано с тем, что при хронической алкогольной интоксикации наблюдается снижение содержания селена, который необходим для синтеза аминокислоты - селеноцистеина, играющего важную роль в катализе [8].

Следует отметить, что повышение активности данного фермента обычно отмечается на первых фазах развития патологических процессов, что связывают с фазой компенсации негативных сдвигов. При длительном хроническом патологическом состоянии данная фаза сменяется декомпенсацией, сопровождающейся истощением антиоксидантной системы организма и, соответственно, падением активности антиоксидантных ферментов. При ЭТГ происходило возрастание активности АСАТ и АЛАТ в сыворотке крови крыс, что являлось следствием цитолиза гепатоцитов $[9,10]$.

В ходе проведенных исследований было выявлено увеличение активности ГП в печени крыс при ЭТГ. Активность фермента возрастала в 2.5 раза по сравнению с группой интактных животных, что, вероятно, является физико-химическим механизмом защитной реакции организма адаптивного характера на стадии компенсации при интенсификации свободнорадикального окисления в условиях развития патологии. Поскольку возникающий в процессе метаболизма $\mathrm{CC}_{4}$ трихлорметильный радикал повреждает клеточные мембраны и стимулирует образование гидропероксидов органических кислот и липидов, то, очевидно, на их обезвреживание и направлена работа данного звена ферментативной АОС. Из литературных источников известно, что ГП относится к группе индуцируемых ферментов, содержание которых в клетке возрастает в результате, например, индуктивного действия органических и неорганических пероксидов.

Известно, что эффективность биологического катализа в клетке может регулироваться как путем изменения количества фермента, так и путем регулирования его активности. Для выяснения взаимосвязи изменений активности ГП с более быстрыми регуляторными механизмами, направленными непосредственно на конформацию молекулы фермента, были разработаны способы очистки и получены гомоген- 
ные ферментные препараты ГП из печени крыс контрольной группы и животных с ЭТГ (табл. 1).

Таблица 1. Очистка глутатионпероксидазы из печени контрольных животных и крыс с токсическим гепатитом

\begin{tabular}{|c|c|c|c|c|}
\hline \multicolumn{2}{|c|}{ Стадия очистки } & $\begin{array}{c}\text { Удельная активность, } \\
\text { Е/мг белка }\end{array}$ & Выход, \% & $\begin{array}{c}\text { Степень } \\
\text { очистки }\end{array}$ \\
\hline \multirow{2}{*}{ Гомогенат } & норма & $0.013 \pm 0.001$ & 100 & 1 \\
\cline { 2 - 5 } & ЭТГ & $0.035 \pm 0.000$ & 100 & 1 \\
\hline $\begin{array}{c}\text { Хроматография на } \\
\text { сефадексеG-25 }\end{array}$ & норма & $0.019 \pm 0.000$ & 90.15 & 1.46 \\
\cline { 2 - 5 } & ЭТГ & $0.077 \pm 0.002$ & 85.01 & 2.20 \\
\hline $\begin{array}{c}\text { Хроматография на ДЭАЭ- } \\
\text { целлюлозе }\end{array}$ & норма & $0.510 \pm 0.015$ & 40.15 & 39.23 \\
\cline { 2 - 5 } $\begin{array}{c}\text { Концентрирование с помо- } \\
\text { щью ячейки Аmісоп }\end{array}$ & ЭТГ & $1.545 \pm 0.052$ & 29.12 & 44.14 \\
\cline { 2 - 5 } & ЭТГа & $0.930 \pm 0.037$ & 20.07 & 71.54 \\
\hline Хроматография на Тоуореarl & норма & $2.384 \pm 0.083$ & 21.95 & 68.11 \\
\cline { 2 - 5 } & ЭТГ-65 & $3.462 \pm 0.044$ & 7.20 & 112.46 \\
\hline
\end{tabular}

Примечание: отличия от нормы достоверны (уровень значимости - $<<0.05$ ).

Таким образом, с помощью разработанной схемы очистки были получены очищенные в 112.46 и 104.11 раз ферментные препараты ГП с удельной активностью $1.462 \pm 0.044$ и $3.644 \pm 0.178$ Е/мг белка из гепатоцитов крыс в норме и при ЭТГ соответственно. Выход составил 7.2 и $8.00 \%$ для фермента из нормальной и пораженной $\mathrm{CCl}_{4}$ печени. Полученный процент выхода фермента свидетельствует о том, что используемая комбинация хроматографических методов позволяет выделить чистыйферментный препарат с относительно небольшими потерями.

Исследование чистоты полученного после гель-хроматографии на Toyopearl HW-65 ферментного препарата с помощью метода гель-электрофореза в ПААГ показало, что фермент как в норме, так и при патологии был получен в гомогенном состоянии (рис. 1.).

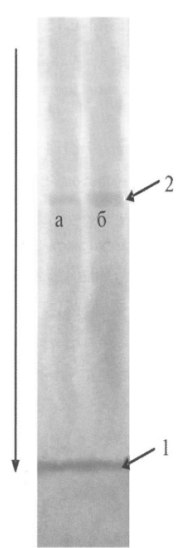

Рис. 1. Электрофореграмма ферментного препарата глутатионпероксидазы из печени крысы в норме (а) и при введении $\mathrm{CCl}_{4}($ б), после окрашивания на белок:

1 - ГП; 2 - фронт маркера. Направление движения белка указано стрелкой

При изучении зависимости скорости ферментативной реакции от концентрации субстрата установлено, что кинетика ферментативной реакции, катализируемой ГП, подчиняется уравнению Михаэлиса-Ментен. Величины Км, определенные методом двойных обратных координат, для ГП, выделенной из печени контрольных крыс, составляют 0.033 мМ по отношению к GSH и 0.208 мМ для $\mathrm{H}_{2} \mathrm{O}_{2}$. Выявлено, что при ЭТГ происходит снижение Км фермента к GSH в 3 раза (Км=0.011 мМ). Для 
$\mathrm{H}_{2} \mathrm{O}_{2}$ величина Км составляет 0.185 мМ. Согласно данным литературы, фермент относительно насыщен GSH, но в большинстве тканей не насыщен $\mathrm{H}_{2} \mathrm{O}_{2}$; промежуточное положение занимают органические гидропероксиды. Считают, что реальная активность ГП in vivo намного меньше максимальной in vitro и лимитируется количеством возникающего $\mathrm{H}_{2} \mathrm{O}_{2}$. Увеличение сродства ГП к $\mathrm{GSH}$ и $\mathrm{H}_{2} \mathrm{O}_{2}$ при токсическом поражении печени крыс вероятно, взаимосвязано с изменением содержания данных метаболитов в клетке при окислительном стрессе.

Исследование термостабильности ГП из печени исследуемых групп животных выявило, что фермент достаточно устойчив к высоким температурам (рис. 2). На начальном этапе инкубации фермента из печени контрольных животных при температуре $30^{\circ} \mathrm{C}$ в течении 3.5 часов наблюдалось незначительная потеря активности (-10\%), однако в течении данного промежутка времени фермент, выделенный из печени животных с интоксикацией $\mathrm{CC}_{4}$, терял $62 \%$ начальной активности. Термостатирование ГП при температуре $40^{\circ} \mathrm{C}$ в течении 2.5 часов приводило к снижению активности фермента на 50\% в условиях нормы и более чем на $80 \%$ при токсическом поражении печени. Инкубация ферментного препарата при $50,60,70^{\circ} \mathrm{C}$ сопровождались инактивацией фермента в течении 75, 60, 45 мин соответственно как в норме, так и при токсическом гепатите.

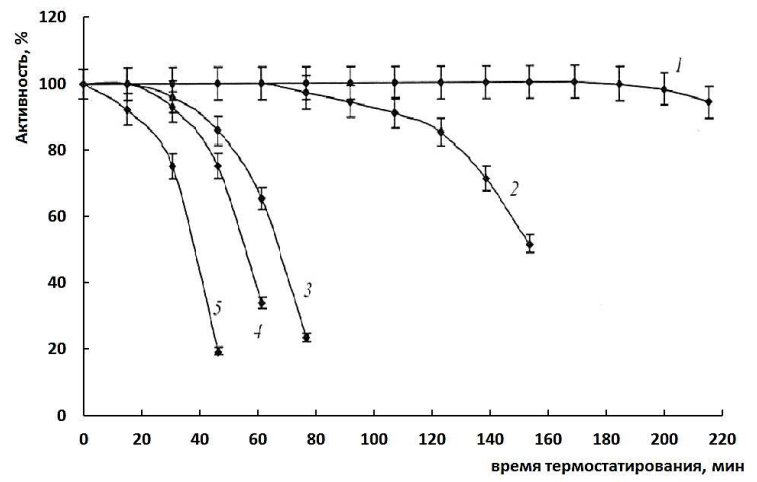

A

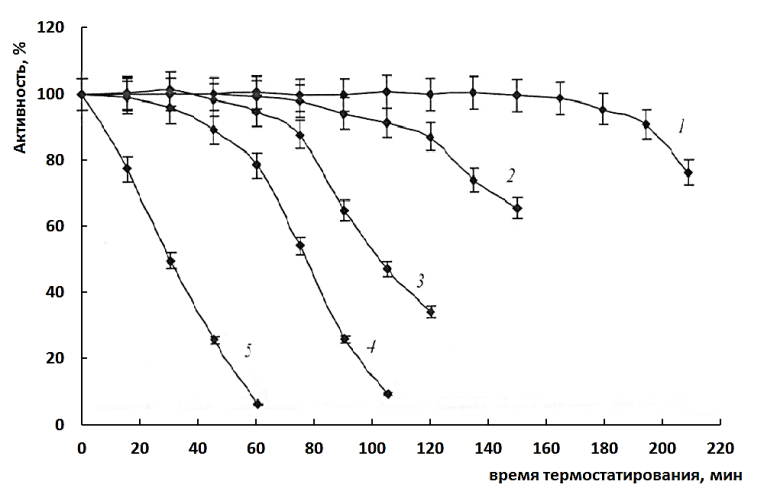

Рис. 2. Кривые инактивации глутатионпероксидазы из печени контрольных (А) и подвергнутых экспериментальному токсическому гепатиту (Б) крыс при $30^{\circ} \mathrm{C}(1), 40^{\circ} \mathrm{C}(2), 50^{\circ} \mathrm{C}(3), 60^{\circ} \mathrm{C}(4), 70^{\circ} \mathrm{C}(5)$.

Таким образом, установлено, что при токсическом гепатите ГП менее устойчива к длительному воздействию температур по сравнению с ферментом из печени контрольных животных. Не исключено, что это может быть связано со структурными изменениями молекулы фермента, происходящими при ишемическом повреждении ткани печени, вызванным экспериментальным токсическим гепатитом.

Влияние температуры на активность ГП из нормальной и пораженной токсическим гепатитом печени крыс отражено на рисунке 3. Температурный оптимум для ГП в норме составил $35^{\circ} \mathrm{C}$, а при ЭТГ $-45^{\circ} \mathrm{C}$. Максимальная активность ГП в норме приходилась на интервал температур от 25 до $35^{\circ} \mathrm{C}$, при токсическом поражении печени от 35 до $45^{\circ} \mathrm{C}$. Различия в температурных оптимумах действия ГП в условиях нормы и при ЭТГ, очевидно, связаны с изменениями в структуре фермента, вызванным окислительным стрессом, возникающим при патологии. Были определены константы инактивации (К Кнакт $)$ и энергия активации $\left(\mathrm{E}_{\text {акт }}\right)$ фермента. Обнаружено, что при увеличении температуры термостатирования ферментных препаратов происходит резкое падение активности ГП во всех исследуемых группах животных. Однако следует отметить, что ГП из печени контрольных крыс была более устойчива к воздействию температурного фактора. 


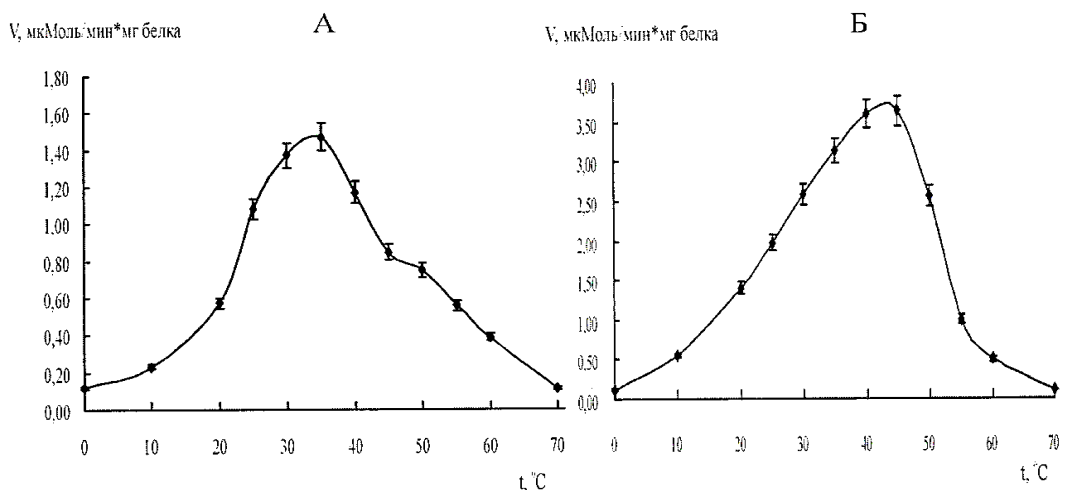

Рис. 3. Влияние температуры на активность глутатионпероксидазы из печени крыс контрольной группы (A) и группы с экспериментальным токсическим гепатитом (Б)

При ЭТГ происходит увеличение констант инактивации ГП приблизительно в 2.3-4.6 раз. Энергия активации ГП в норме и при токсическом гепатите, определенная в интервале температур $30-70^{\circ} \mathrm{C}$, составила 29.1 и 8.2 кДж. Уменьшение энергии активации ГП может быть связано с изменением условий функционирования фермента в условиях токсического гепатита.

\section{Заключение}

Таким образом, выявлены изменения активности ГП по сравнению с контрольными значениями как у больных АГ, так и при ЭТГ у животных. Для выяснения возможных физико-химических механизмов изменения активности фермента были разработаны способы очистки ГП из печени крыс исследуемых групп животных. Исследование свойств ГП с применением очищенных ферментных препаратов позволяет предполагать, что одним из механизмов, сопряженных с возрастанием активности фермента при нарушении функции печени, могут быть конформационные перестройки молекулы в условиях усиленной генерации свободных радикалов.

\section{Список литературы}

1. Калинин А.В. // Фарматека. 2005. №1(97). C. 48-55.

2. Горбенко М.В., Попова Т.Н., Шульгин К.К., Попов С.С. // Экспериментальная и клиническая фармакология. 2013. Т. 76. № 10. С. 12-15.

3. Андреещева Е.М., Попова Т.Н., Артюхов В.Г., Матасова Л.В. // Бюллетень экспериментальной биологии и медицины. 2004. № 4. C. 399-402.

4. Davis B.J., Jones R.G., Farmer G.R. // Ann. N. Y. Acad. Sci. 1964. Vol. 121. pp. 404427.

5. Shevchenko A., Wilm H., Vorm O. // Anal. Chem. 1996. Vol. 68. pp.850-858.
6. Lowry O.H., Rosebrough N.J., Farr A.L., Randall R.J. // J. Biol. Chem. 1951. Vol. 193. pp. 265-275.

7. Гланц С. Медико-биологическая статистика. М. Практика. 1999. 459 с.

8. Kim J.H., Park S.H., Nam S.W., Choi Y.H. // Int. J. Mol. Sci. 2012. Vol. 13. pp. 57405750.

9. Попов С.С., Пашков А.Н., Попова Т.Н., Семенихина А.В. и др. // Экспериментальная и клиническая фармакология. 2007. T. 70. № 1. C. 48-51.

10. Попов С.С., Пашков А.Н., Попова Т.Н., Золоедов В.И. и др. // Бюллетень экспериментальной биологии и медищины. 2007. № 8. C. 170-173. 


\title{
The activity and catalytic properties of glutathione peroxidase at liver toxic disturbance
}

\author{
Shul'gin Konstantin K. ${ }^{1}$, Popov Sergey S. ${ }^{2}$, Verevkin Alexey N. ${ }^{1}$, \\ Popova Tatyana N. ${ }^{1}$, Semenikhina Anastasiya V. ${ }^{1}$, \\ ${ }^{I}$ Voronezh State University, Voronezh \\ ${ }^{2}$ Voronezh State Medical University named by N.N. Burdenko, Voronezh
}

\begin{abstract}
The aim of this study was investigation of the functioning of glutathione peroxidase (GPx, EC 1.11.1.9.) under the condition of impaired liver function and purification of the enzyme by chromatographic methods for the further investigation of its kinetic properties. The blood serum of patients with alcoholic hepatitis, undergoing in-patient treatment was used in the experiment. The control group included apparently healthy individuals with normal complete blood count and comprehensive biochemical profile results. Experimental toxic hepatitis (ETH) was modelled by oral administration of carbon tetrachloride to male albino Wistar rats (Rattus norvegicus). The control group included healthy animals kept under standard vivarium conditions. The activity of GPx was measured spectrophotometrically at a wavelength of $340 \mathrm{~nm}-$ based on a coupled enzymatic reaction with glutathione reductase. The purification of glutathione peroxidase obtained from healthy rat liver and the liver of rats with toxic hepatitis was performed by homogenisation of the material, gel-filtration on Sephadex G-25, ion-exchange chromatography on DEAE-cellulose, concentration of the enzyme fractions inan Amicon ultrafiltration cell, and gel chromatography on Toyopearl HW-65. The purity of the obtained enzyme preparation was evaluated using the electrophoretic method. The total protein content of the samples was determined according to the Lowry method. The study demonstrated an increase in the activity of the pathology markers in the blood serum of patients with alcoholic hepatitis and rats with ETH. The activity of GPx in the blood serum of patients with alcoholic hepatitis and in liver homogenate of rats with ETH also changed as compared to the control level. As a result of the experiment, enzyme preparations were obtained from the livers of healthy rats and rats with ETH. They had a specific activity of 1.46 and $3.64 \mathrm{U} / \mathrm{mg}$, and a yield of 7.2 and $8.0 \%$ respectively. These preparations were then used to study the kinetic properties of GPx. It was determined that during toxic hepatitis GPx is less resistant to prolonged exposure to high temperatures as compared to the enzyme from the liver of a healthy animal. In addition, during pathology the optimum temperature for enzyme activity and inactivation constants also increased. The obtained results allow us to suggest that the change in the activity of the enzyme under impaired liver function can be caused by conformational changes of the enzyme molecule - under conditions of the increased generation of free radicals.
\end{abstract}

Keywords: toxic hepatitis, glutathione peroxidase, activity, purification.

\section{References}

1. Kalinin A.V., Farmateka, 2005, No 1(97), pp. 48-55.

2. Gorbenko M.V., Popova T.N., Shul'gin K.K., Popov S.S., Eksperimental'naia i klinicheskaia farmakologiia, 2013, Vol. 76, No 10, pp. 12-15.

3. Andreeshcheva E.M., Popova T.N., Artyukhov V.G., Matasova L.V., Bulletin of experimental biology and medicine, 2004, No 4, pp. 399-402.

4. Davis B.J., Jones R.G., Farmer G.R., Ann. N. Y. Acad. Sci., 1964, Vol. 121, pp. 404-427. DOI: 10.1111/j.1749-6632.1964.tb14213.x

5. Shevchenko A., Wilm H., Vorm O., Anal. Chem., 1996, Vol. 68, pp. 850-858. DOI: 10.1021/ac950914h
6. Lowry O.H., Rosebrough N.J., Farr A.L., Randall R.J., J. Biol. Chem., 1951, Vol. 193, pp. 265-275.

7. Glants S., Mediko-biologicheskaya statistika, M., Praktika, 1999, 459 p.

8. Kim J.H., Park S.H., Nam S.W., Choi Y.H., Int. J. Mol. Sci., 2012, Vol. 13, pp. 57405750. DOI: $10.3390 / \mathrm{ijms} 13055740$

9. Popov S.S., Pashkov A.N., Popova T.N., Semenikhina A.V. et al., Eksperimental'naia $i$ klinicheskaia farmakologiia, 2007, Vol. 70, No 1, pp. 48-51.

10.Popov S.S., Pashkov A.N., Popova T.N., Zoloedov V.I. et al., Bulletin of Experimental Biology and Medicine, 2007, No 8, pp. 170-173. 
Шульгин Константин Константинович к.б.н., доцент кафедры медицинской биохимии и микробиологии, Воронежский государственный университет. Воронеж

Попов Сергей Сергеевич - д.м.н., профессор кафедры госпитальной терапии и эндокринологии, Воронежский государственный медицинский университет имени Н.Н. Бурденко, Воронеж

Веревкин Алексей Николаевич - к.б.н., ассистент кафедры медицинской биохимии и микробиологии, Воронежский государственный университет, Воронеж

Попова Татьяна Николаевна - д.б.н., профессор кафедры медицинской биохимии и микробиологии, Воронежский государственный университет, Воронеж

Семенихина Анастасия Владимировна к.б.н., медицинской биохимии и микробиологии, Воронежский государственный университет. Воронеж
Shulgin Konstantin K. - Ph.D. (biology), associate prof., department of medical biochemistry and microbiology; Voronezh State University, Voronezh, e-mail: kkshulgin@mail.ru

Popov Sergei S. - grand Ph D (medicine, MD), prof., department of hospital therapy and endocrinology, Voronezh State Medical University named after N. N. Burdenko, Voronezh, e-mail: popov-endo@mail.ru

Verevkin Aleksei N. - Ph.D. (biology), assistant, department of medical biochemistry and microbiology; Voronezh State University, Voronezh, e-mail: wer.all@ mail.ru

Popova Tatyana N. - prof., grand $\mathrm{PhD}$ (biology), department of medical biochemistry and microbiology, Voronezh State University, Voronezh, e-mail: biomed-popova@vandex.ru

Semenikhina Anastasia V. - Ph D (biology), associate prof., Department of medical biochemistry and microbiology. Voronezh State University. Voronezh, E-mail: semenikhina@ bio.vsu.ru 